\title{
PERANCANGAN FASHIONABLE APD UNISEX DENGAN TEKNIK SUMINAGASHI
}

\author{
Fabio Ricardo Toreh, Marini Yunita Tanzil, B.Com.Des, M.Fashion \\ Universitas Ciputra, Surabaya 60219, Indonesia \\ fabio.toreh@ciputra.ac.id \\ marini.yunita@ciputra.ac.id
}

\begin{abstract}
This design was carried out in order to create Fashionable PPE for unisex with the Suminagashi technique. This design is in accordance with the needs of the times, which is to remain fashionable but health is also maintained during the COVID-19 pandemic. The materials used are very functional and also water repellent. This writing uses quantitative methods using primary data collection techniques and secondary data. Primary data through observation, and questionnaires. As well as secondary data through books, journals, articles, and the internet. The final result is Fashionable PPE with the Suminagashi technique for unisex aged 25-45 years, upper middle class and has an interest in fashion.
\end{abstract}

Keywords: Fashionable, PPE, Suminagashi, Water repellent, Functional

\begin{abstract}
ABSTRAK
Perancangan ini dilakukan dalam rangka menciptakan APD Fashionable untuk unisex dengan teknik Suminagashi. Adapun perancangan ini sesuai dengan kebutuhan zaman yaitu tetap fashionable namun kesehatan juga terjada selama masa pandmei covid 19. Bahan yang digunakan sangat fungsional dan juga water repellent. Penulisan ini menggunakan metode kuantitatif dengan menggunakan teknik pengumpulan data primer dan data sekunder. Data primer melalui observasi, dan kuesioner. Serta data sekunder melalui buku, jurnal, artikel, dan internet. Adapun hasil akhir yaitu APD Fashionable dengan teknik Suminagashi untuk unisex berusia 25-45 tahun, kalangan menengah ke atas dan memiliki ketertarikan di bidang fesyen.
\end{abstract}

Kata Kunci: Fashionable, APD, Suminagashi, Water repellent, Fungsional 


\section{PENDAHULUAN}

\section{Latar Belakang Masalah}

Manusia memiliki banyak kebutuhan yang beragam dalam menjalani kehidupan. Pada saat pandemi seperti ini semakin menambah variasi kebutuhan manusia. Meskipun demikian, kebutuhan utama terhadap pangan, sandang, dan papan yang tetap menjadi prioritas dalam hal permintaan kebutuhan masyarakat (Mubarok, 2018). Meskipun Fashion sebenarnya memiliki arti segala sesuatu yang sedang trend di dalam masyarakat, namun seringkali dikaitkan dengan busana atau pakaian (Trisnawati, 2011).

Saat ini perkembangan kebutuhan sandang manusia baru saja mengalami perubahan secara signifikan, dikarenakan terjadinya pandemic dari virus Covid-19 yang dapat menginfeksi sistem pernapasan manusia secara ringan dengan gejala yang menyerupai flu hingga dapat menyebabkan infeksi pernapasan berat seperti Pneumonia (Karyono, Rohadin, \& Indriyani, 2020).

Berdasarkan data yang diunduh dari website worldometer (2019) tren dari kasus aktif dan kasus kematian mengalami peningkatan terus menerus hingga saat ini. Untuk mengatasi hal tersebut, menurut sumber dari PERDALIN KOTAPRAJA (Wahyutomo, 2020), bahwa APD pada umumnya adalah alat kesehatan yang berfungsi untuk melindungi diri dari kontaminasi penyakit infeksi, sehingga dapat berupa masker, topi, sarung tangan, pelindung wajah, serta sepatu.
Seperti yang sudah disosialisasikan oleh pemerintah Indonesia melalui website www. covid19.go.id, bahwa APD dengan jenis Gaun isolasi bedah steril dan Coverall hanyalah diperuntukkan tenaga medis saja agar dapat memastikan ketersediaan APD jenis ini secara tepat guna. Terkait dengan permasalahan yang sudah diuraikan diatas, maka Brand Bio akan memberikan solusi pada masyarakat yang hendak melakukan proteksi dengan standar yang tepat dengan menciptakan design busana outerwear APD yang fashionable dengan menggunakan sistem jahitan seam sealer berbahan water repellent dan aplikasi teknik Suminagashi sebagai identitas dari desain ini.

\section{Rumusan Masalah}

"Bagaimana merancang APD Fashionable untuk unisex dengan teknik Suminagashi?"

\section{Tujuan Perancangan}

Tujuan perancangan Tugas Akhir ini adalah Merancang Fashionable APD untuk unisex dengan teknik Suminagashi.

\section{Batasan Perancangan}

Berikut merupakan batasan perancangan, yakni:

1. Batasan Keilmuan, yakni ruang lingkup ilmu Desain Fesyen

2. Batasan Material, yakni menggunakan material anti air cleona satin dengan tingkat proteksi sesuai dengan standard WHO yang telah di support dari PT. Gistex sebagai bahan shell fabric, serta bahan penunjang lain 
seperti kain Rib, ultimate wool, dsb. Aplikasi retsleting waterproof, snap button, draw strings, D-rings, dsb.

3. Batasan Pasar :

a) Geografis, yakni batasan wilayah pada kota-kota besar di Indonesia seperti Surabaya dan Jakarta

b) Demografis, yakni fokus kepada wanita maupun pria yang memiliki aktifitas diluar rumah dengan rentang usia antara 25-45 tahun dengan status sosial menengah ke atas.

c) Psikografis, yakni berdasarkan teori VALS merupakan kelompok Thinkers dan Achiever.

4. Batasan Waktu : Januari 2021-Juni 2021

\section{TAHAPAN PERANCANGAN}

Proses perancangan ini menggunakan metode Design Thinking menurut Dam \& Siang (2018), yakni :

\section{a) Emphatise}

Pada tahap ini, penulis menemukan pemahaman empatik akan kebutuhan busana yang diperlukan pada masa pandemi ini bagi wanita atau pria usia 25-45 tahun yang memiliki aktivitas indoor maupun outdoor.

b) Define

Pada tahap define, penulis melakukan proses pengumpulan data, analisa pengamatan dan mensistesisnya guna mendapatkan inti dari permasalahan yang sudah teridentifikasikan guna membangun fitur, fungsi maupun elemen lain yang diperlukan dalam penyelesaian masalah atau setidaknya meminimalisirkan kesulitan pengguna. Pasar membutuhkan Outerwear APD dengan desain fashionable yang praktis dan memiliki fitur fungsional yang membantunya melakukan proteksi mandiri baik untuk beraktivitas didalam maupun diluar ruangan.

c) Ideate

Pada tahap ideate, penulis melakukan brainstorming dengan expert dengan menjalankan teknik ideation SCRAMPER, sehingga menghasilkan desain outerwear APD yang mempunyai standarisasi cukup untuk proteksi diri melalui penggunaan teknik jahit Seam sealer, menggunakan bahan utama yang memiliki sifat water repellent, serta dilengkapi dengan beberapa fitur fungsional namun masih memiliki desain yang fashionable.

d) Prototype

akan dibuat sampling menggunakan bahan riil berdasarkan dari ide-ide sebelumnya untuk melakukan identifikasi solusi terbaik dari setiap masalah yang ditemui sebelumnya guna validasi dari solusi tersebut, hingga dapat memiliki pandangan terbaik akan apa yang akan dirasakan dan reaksinya ketika berinteraksi dengan finish product tersebut.

\section{e) Test}

Test merupakan tahap akhir yang melakukan pengujian terhadap produk akhir secara ketat dengan menggunakan solusi yang dianggap terbaik pada proses prototyping kepada calon konsumen hingga tervalidasi 
melalui feedback apakah dapat diterima dan bermanfaat. Setelah itu keseluruhan hasil prototype akhir dapat dipresentasikan secara utuh kepada dosen pembimbing.

\section{Metode Pengumpulan Data}

Metode penelitian yang digunakan perancangan ini adalah metode deskriptif kuantitatif. Menurut Silalahi (2015), perancangan deskriptif kuantitatif adalah perancangan suatu fenomena dengan fokus pertanyaan "apa" dan "bagaimana" yang mengacu kepada identifikasi sifat yang membedakan atau karakteristik sekelompok obyek.

\section{Pengumpulan Data Primer}

a) Metode survei, menurut Siregar (2013), memungkinkan perancang untuk mempelajari sikap, opini, keyakinan, karakter, dan perilaku dalam suatu organisasi.

b) Kuesioner yang digunakan, perancangan ini menggunakan kuesioner dengan pertanyaan tertutup dan terbuka (open and closed-ended question) terhadap enam orang expert dan juga enam extreme user yang sesuai dengan target pasar yang sudah ditentukan yaitu perempuan maupun laki-laki berumur 25-45 tahun yang menyukai berbagai hal terkait fashion dan menyukai tampil fashionable.

c) Observasi, studi tipologi menganalisa 3 Brand yang berkaitan dengan outerwear APD, sportswear, ready to wear.

\section{Pengumpulan Data Sekunder}

Studi Literatur, yakni pengumpulan data diperoleh melalui buku jurnal, artikel, serta dari website atau internet yang relevan sebagai penunjang untuk menyelesaikan Tugas Akhir ini.

\section{TINJAUAN DATA}

\section{Teori Minimalis}

Minimalis merupakan konsep bertema asal dari kesederhanaan. Penggunaan elemen yang paling sederhana dan digunakan pula dengan sedikit untuk menciptakan efek yang maksimal (Eladwi \& Kotb, 2015).

\section{Teori Busana Uniseks (Unisex)}

Busana pada unisex fesyen memiliki keuntungan yaitu memiliki jenis yang lebih beragam dan tidak dibatasi oleh gender seperti rok, celana, dress, suit, dan masih banyak lagi. Busana, warna, siluet, sudah tidak lagi memiliki gender atau tidak menjadi orientasi gender tertentu dan dapat terlihat dalam koleksi dari banyak fashion designer di Indonesia (Githapradana, 2018).

\section{TEKNIK PEMBUATAN}

Teknik Suminagashi

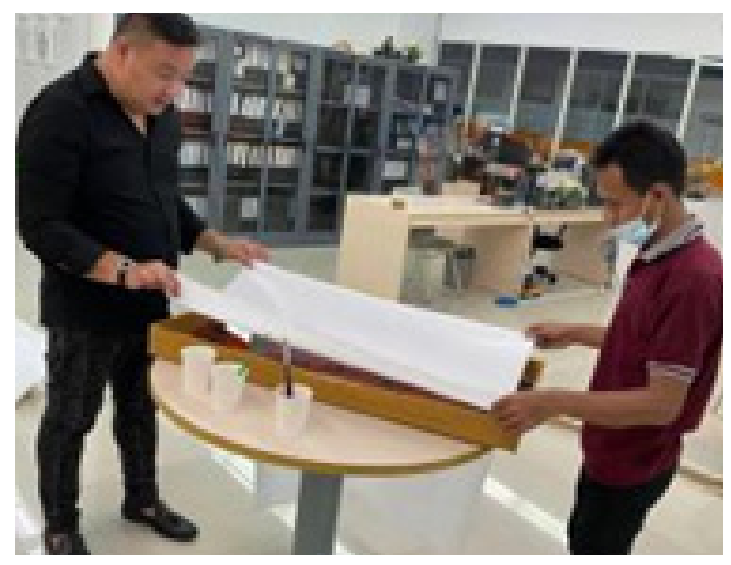

Gambar 1. Langkah Pembuatan Teknik Suminagashi Sumber: Perancang, 2021 
Suminagashi atau biasa disebut Marbling atau juga disebut Ebru berasal dari Jepang pada awal abad ke-12. Teknik Suminagashi merupakan teknik kuno yang telah banyak digunakan dengan melukis diatas air yang hasil akhirnya memiliki tekstur seperti marmer. Teknik ini dimulai dengan sebuah tinta maupun cat yang mengapung di atas air. Hal ini dilakukan secara sengaja lalu dibentuk atau dipola dan kemudian diserap menggunakan sebuah media lain. Untuk mendapatkan pola tersebut dapat menggunakan kertas atau kanvas atau media yang lainnya asalkan media tersebut memiliki daya serap tinggi. Cara mendapatkan pola dengan menempelkan media tersebut pada tinta atau cat yang sedang terapung di permukaan air (Zarkasi \& Sukirno, 2018).

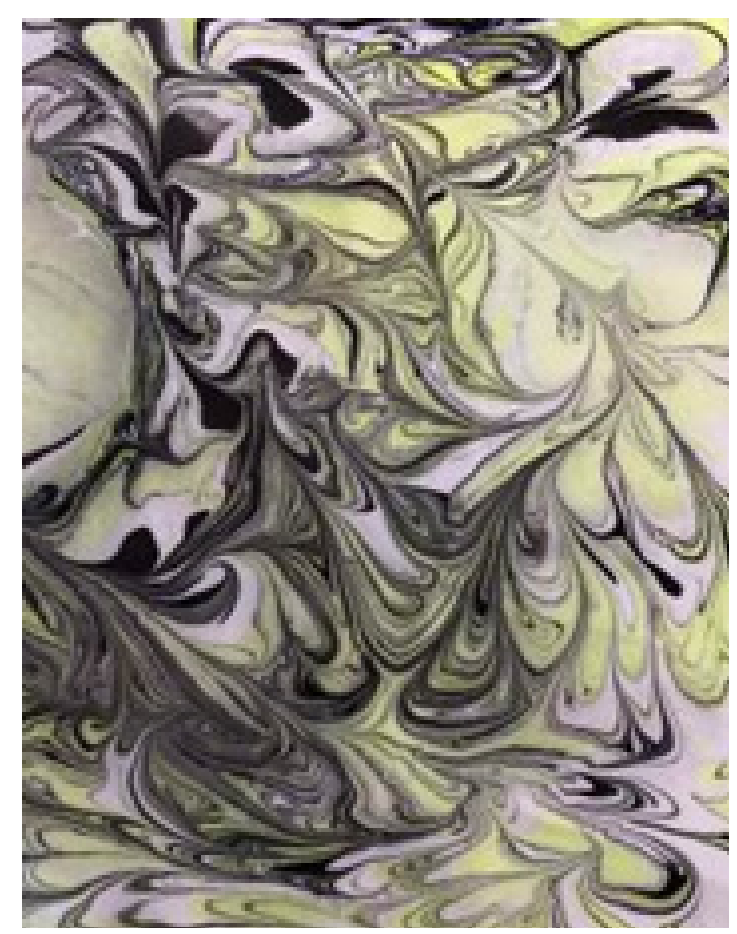

Gambar 2. Hasil Teknik Suminagashi Sumber: Perancang, 2021

\section{Teknik Finishing Seam sealer}

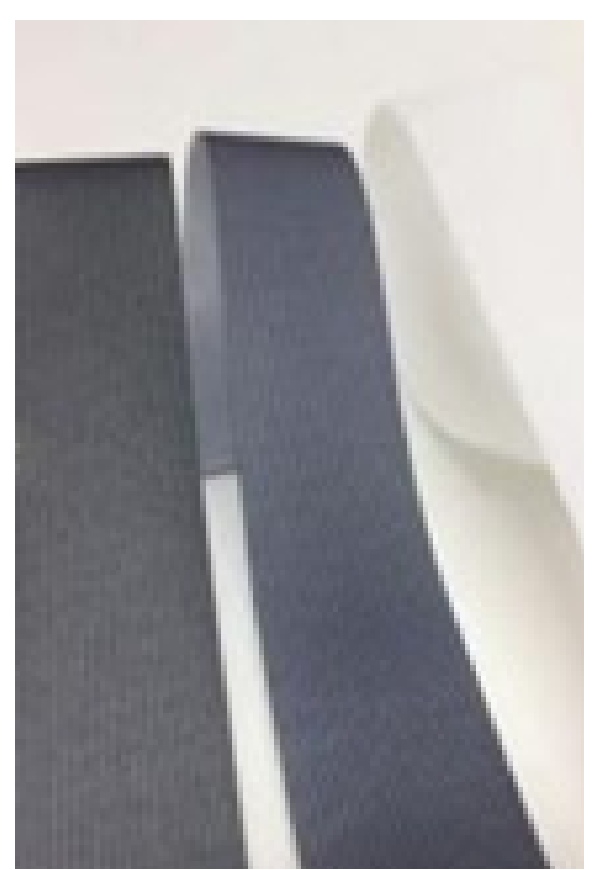

Gambar 3. Seam sealer Tape Sumber: Point North, 2020

Teknik Seam sealer dipilih karena tujuan outerwear yang di desain untuk menahan virus yang ukurannya miskroskopik dengan menambahkan seam sealer. Penambahan ini dilakukan pada bagian yang lubang karena jarum jahit agar mencegah virus tidak dapat masuk. Seam sealer ini digosok menggunakan setrika agar lem nya dapat melekat pada bahan dan biasanya dilekatkan pada sisi buruk kain. Sebagai bagian akhir dilakukan penutupan menggunakan lining agar tidak terlihat.

\section{Elemen Desain}

Dalam elemen desain terbagi menjadi enam bagian dasar yaitu garis, bentuk, tekstur, ruang, 
ukuran dan warna. Pada perancangan ini mengedepankan dua unsur yang pertama adalah garis. Kumpulan titik yang bergabung seringkali kita sebut dengan garis yang merupakan elemen dasar dalam proses desain.

Dalam proses menggambar yang merupakan salah satu seni visual ini menggunakan garis sebagai dasar utama. Garis dalam seni digunakan sebagai alat bantu untuk merepresentasikan sesuatu. Kualitas garis yang dapat diciptakan seseorang berubah seiring tumbuh kembang (Widyokusumo, 2013).

Dalam desain ini yang digunakan adalah menghubungkan satu titik dengan titik lain yang akhirnya membentuk sebuah garis lengkung atau curve yang akhirnya dapat memberikan kesan dinamis dan bergerak. Sebagai tambahan, juga digunakan teknik bias band untuk memberikan efek tegas.

Unsur kedua yang ditonjolkan adalah warna. Pemilihan warna yang digunakan pada desain ini adalah warna monotone dengan penekanan warna stabillo yang memberikan kesan baru dan juga menarik agar membuat desain dari Suminagashi menjadi strong point dari keseluruhan desain outer yang menganut teori desain minimalis.

\section{Prinsip Desain}

Hakekat mengenai suatu komposisi yang baik terjadi apabila setiap proses penyusunan unsur pendukung motif selalu memperhatikan memperhatikan prinsip-prinsip komposisi (Patappa, 2019). Ada lima prinsip desain dasar mulai dari keseimbangan/balance, kesatuan/ unity, ritme/ rhytm, penekanan/ emphasis, dan juga proporsi. Dalam desain yang dilakukan pada tugas akhir ini menggunakan seluruh prinsip desain yang ada, namun menonjol dalam tiga aspek pilihan.

Yang pertama adalah aspek ritme atau rhytm yang merupakan pengulangan pada beberapa detail busana di koleksi seperti lengan raglan, kantong hand sanitizer dan penggunaan bias band serta dari fitur yang selalu mengutamakan fungsi penggunaan. Yang kedua adalah prinsip penekanan atau emphasis yaitu penggunaan detail motif Suminagashi yang sarat akan detail pada desain busana yang cenderung minimalis.

Dan yang terakhir adalah proporsi yang merupakan perbandingan penggunaan Suminagashi yang cenderung sedikit guna tetap mengutamakan desain busana dengan teori minimalis.

\section{Tren Desain}

Tren desain yang ada dalam dunia fesyen dapat dilihat dalam bentuk tren motif. Berbagai corak kain, jenis busana atau bentuknya, tekstur atau bahan, warna, konsep atau tema dan lain sebagainya dapat menjadi tren motf atau desain. Dalam busana unisex sendiri seringkali memiliki tren busana yang oversized dengan warna primer. 


\section{a) Style}

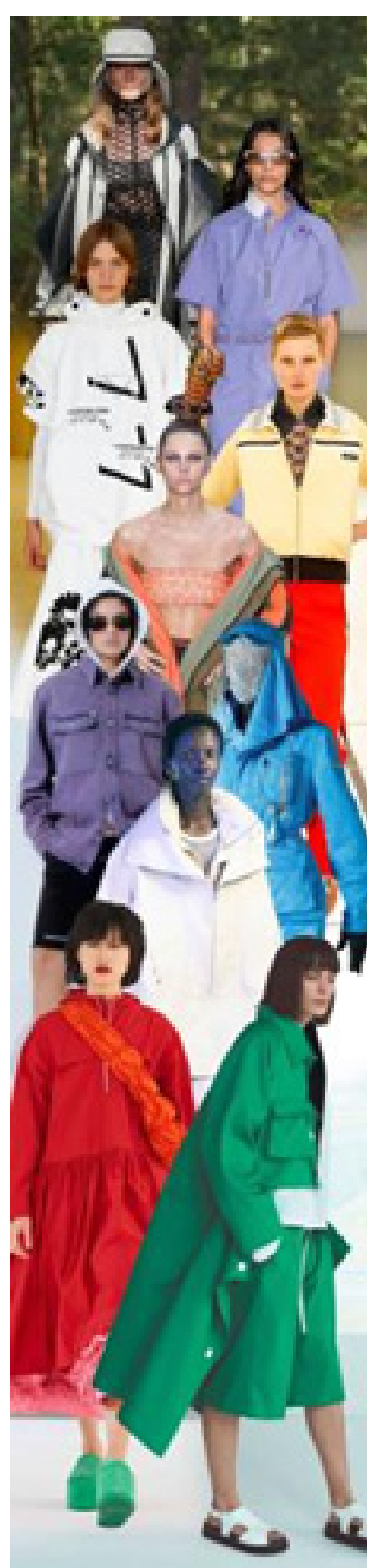

Gambar 4. Tema Team Player SS 2020/2021 Sumber: Harpersbazaar.com, 2021
Style yang dipilih bertema sporty yang masuk ke dalam tren teamplayer untuk Harpersbazaar. Tren yang dipilih ini memiliki tampilan style yang memiliki nuansa hitam dan putih dengan penggunaan Suminagashi yang tidak terlalu banyak sehingga tidak tampil terlalu mencolok. Trend sporty ini cocok dalam konsep unisex karena bentuk yang netral dan dengan kombinasi detil, motif, dan bahan lainnya akan dapat lebih mencerminkan unisex fashion.

\section{b) Graphic}

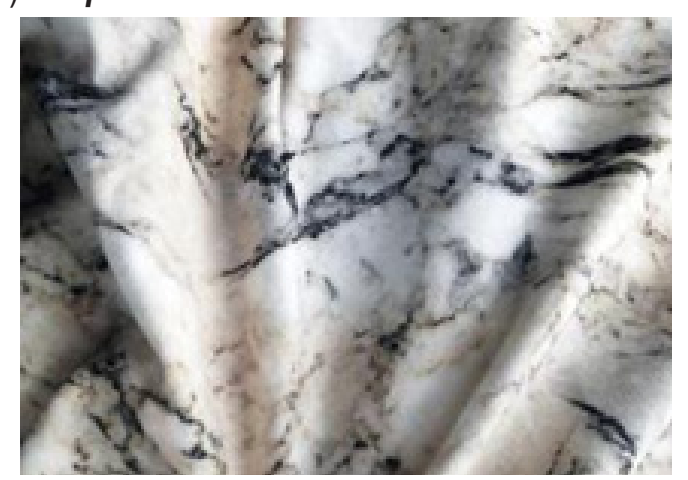

Gambar 5. Tren Marbling 2021

Sumber: bsamply.com, 2021

Dalam tradisi craft di Jepang, suatu teknik yang berasal dari kata sumi artinya adalah tinta dan juga nagashi adalah mengambang sering kali kita sebut dengan Suminagashi. Pada awalnya teknik ini digunakan untuk menghias buku selanjutnya juga digunakan untuk membungkus hadiah atau furoshiki. Pada abad ke-18 terjadi ketertarikan umum terhadap Suminagashi yang juga disebut marbling. Teknik ini merupakan salah satu teknik produksi yang berpotensi sangat besar karena belum popular di masyarakat dan masih banyak dilakukan pengembangan (Hendrawan, 2017). 
c) Warna

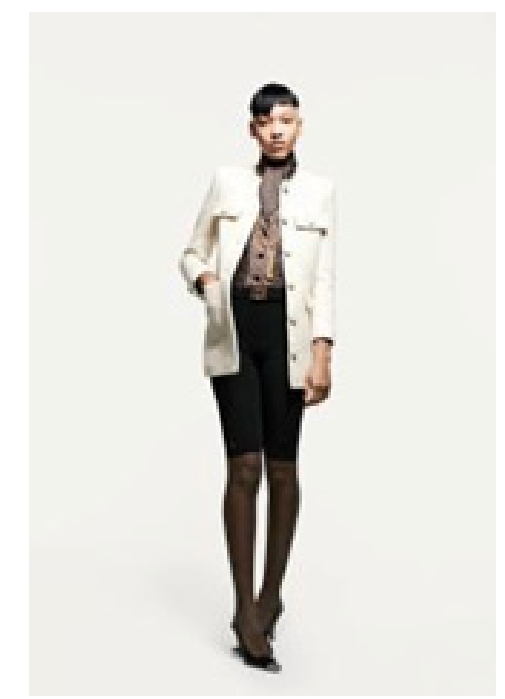

Gambar 6. Tren Warna Monochrome Pada Yves Saint Laurent sumber: Vogue.co.uk, 2021

Warna yang merupakan bagian penting dalam tren desain memiliki banyak jenis. Warna yang dipilih pada desain tugas akhir ini mengunakan tema monochrome trend dari vogue 'Monochrome Magic', lalu dominan hitam dan putih yang menjadi trend utk 2021 serta warna pantone 130647 TCX yaitu illuminating yellow menjadi tren.

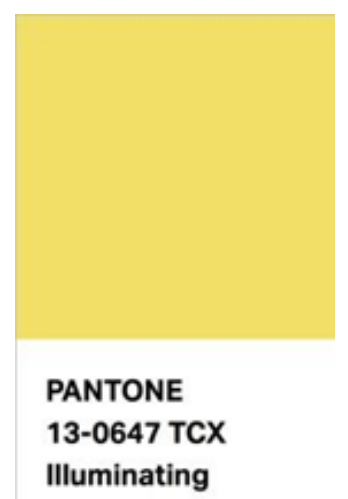

Gambar 7. Tren Warna Illuminating Yellow Pada Pantone 2021-2022

Sumber: Fashiontrensetter.com, 2021 d) Material

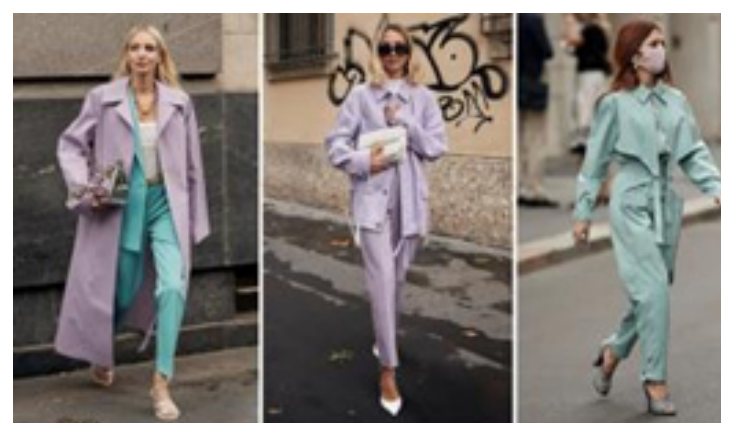

Gambar 8. Tren Bahan Water repellent A/W 2020-2021 Sumber: Thetrendspotter.net, 2021

Material yang dipilih pada tugas akhir ini tentunya adalah hal yang sangat diperhatikan. Mengingat fungsi yang tidak hanya untuk fesyen namun juga sebagai outerwear yang dapat menangkal virus. Material yang dipilih berbahan polyester dengan fitur water repellent menjadi trend pada berbagai label yang terkenal.

\section{KESIMPULAN DAN HASIL PENGGALIAN DATA}

Pada masa pandemi covid yang sudah lebih dari 1 tahun ini berdampak pada berbagai bidang. Tidak terkecuali bidang fesyen yang dituntut untuk tetap menjaga "gaya" namun mengikuti perkembangan jaman. Busana unisex yang ditampilkan pada tugas akhir ini menjadi jawaban untuk masa pandemi yaitu membuat outerwear yang merupakan APD (Alat Pelindung Diri) yang tetap fashionable dan sangat cocok untuk era new normal. Dengan konsep unisex dapat mempermudah semua kalangan untuk dapat menggunakannya karena tidak berorientasi pada salah satu gender saja 


\section{OVERVIEW}

Perancangan outerwear yang bersifat unisex dengan teknik Suminagashi tidak hanya digunakan untuk kesempatan khusus. Desain yang ditampilkan dapat digunakan sehari-hari tanpa takut ada orang lain yang memiliki desain sama persis. Untuk tetap menjaga keamanan dari virus maka bagian yang berlubang akan ditutup dengan seam sealer.

\section{Moodboard}

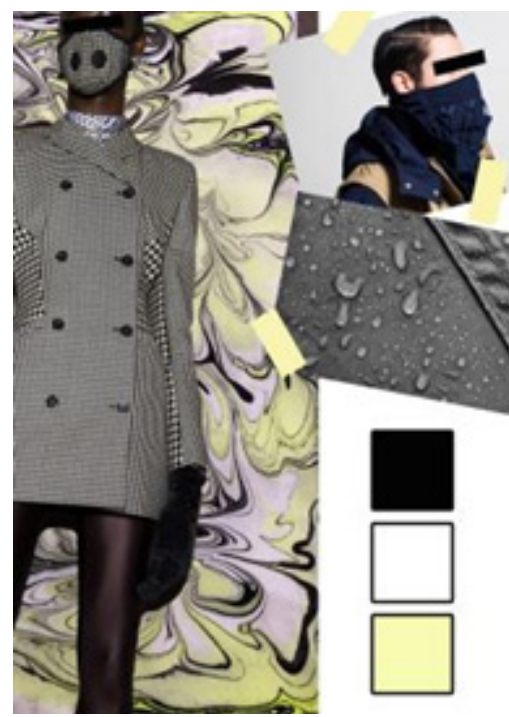

Gambar 9. Moods Koleksi Sumber: Toreh, 2021

Konsep yang diangkat pada moodboard diatas menggunakan bahan water repellent dari PT Gistex yaitu cleona satin. Dengan bahan yang nyaman, outerwear yang bersifat APD tetap terlihat fashionable dan tidak menakutkan. Corak Suminagashi yang ditunjukkan membuat kesan sporty style muncul dengan fitur fungsional tentunya.

\section{ROUGH SKETCH}

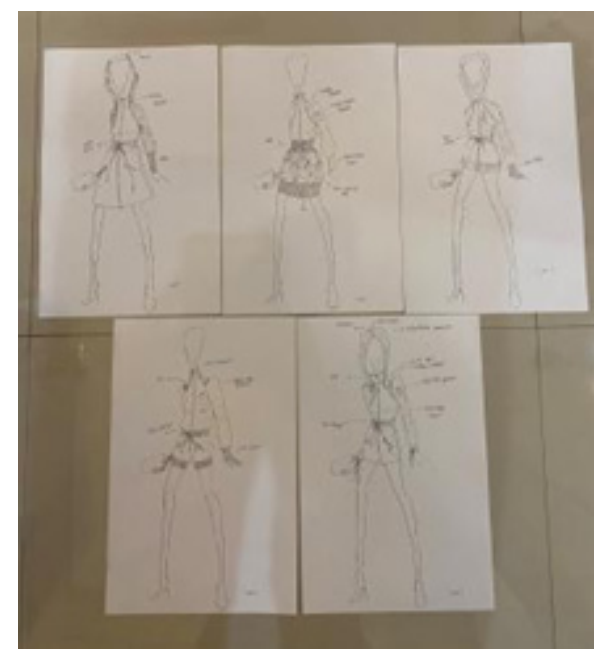

Gambar 10. Raw Sketch Koleksi Sumber: Toreh, 2021

Penempatan desain sporty dengan menggunakan potongan lengan raglan, bahan rib serta detail hoodies. Potongan raglan di emphasis menggunakan penambahan bias band. Mempunyai fitur fungsi: seam sealer, kantong yang dapat dibesarkan, hoodies dengan pengait untuk face shield, kantong tersembunyi, kantong hand sanitizer, dan lain sebagainya. Menggunakan bahan water repellent, zipper waterproof dan seam sealer.

\section{FINAL DESIGN}

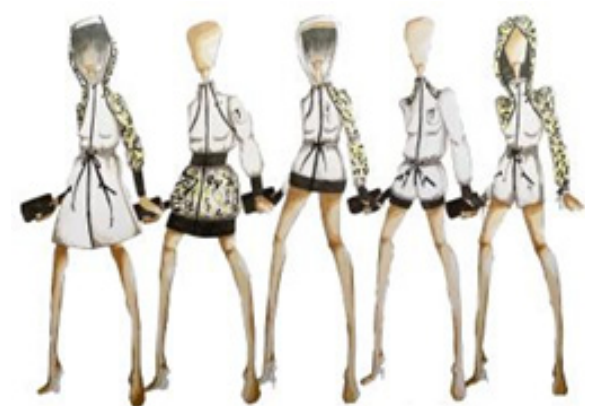

Gambar 11. Sketch Warna Dari Koleksi Sumber: Toreh, 2021 
Penempatan Suminagashi sudah dipikirkan dengan memperhatikan teori minimalis. Penggunaan bahan juga sudah disesuaikan dengan fungsi dan kebutuhan, seperti rib untuk bagian yang harus elastis untuk kenyamanan, atau zipper untuk memudahkan atau membuat fungsi adjustable. Draw strings untuk memberikan efek kerut serta memperkecil volume pada bagian yang memerlukan hal ini.

\section{SELECTED DESIGN}

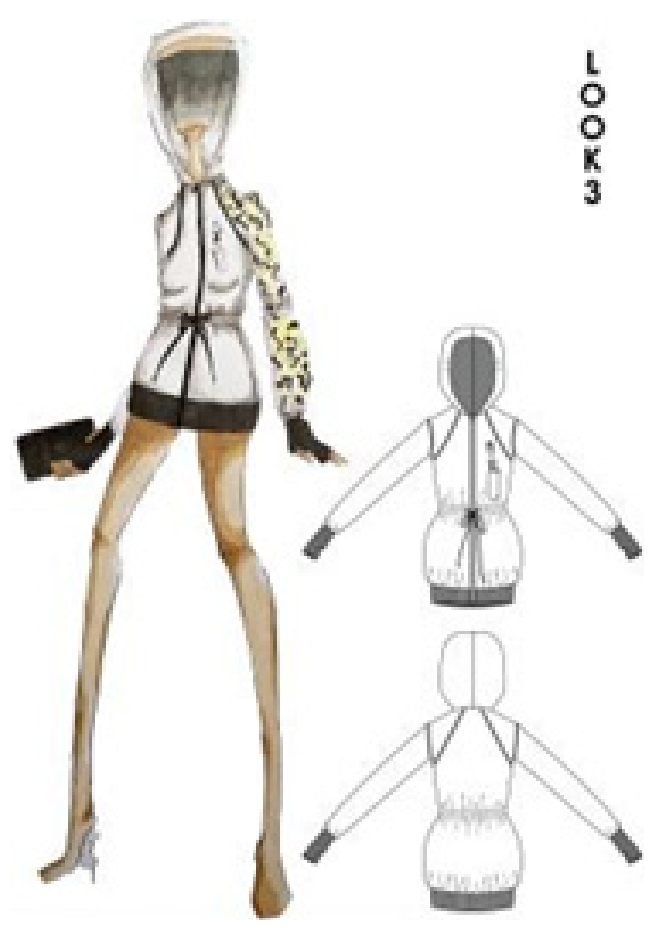

Gambar 12. Sktech Terpilih Beserta Technical Drawing Sumber: Toreh, 2021

Berdasarkan Survei yang dilakukan secara keseluruhan terpilih look 3,4,5 dan yang akan diwujudkan adalah look 3 .

\section{FINAL PROTOTYPE}

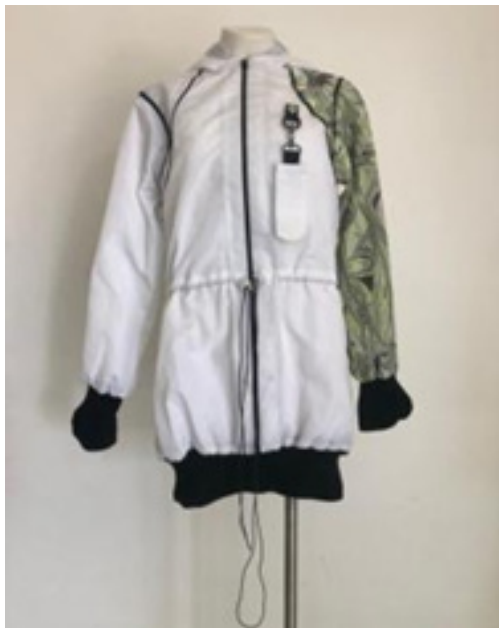

Gambar 13. Cek Volume Prototype Look 3 Tampak depan Sumber: Toreh, 2021

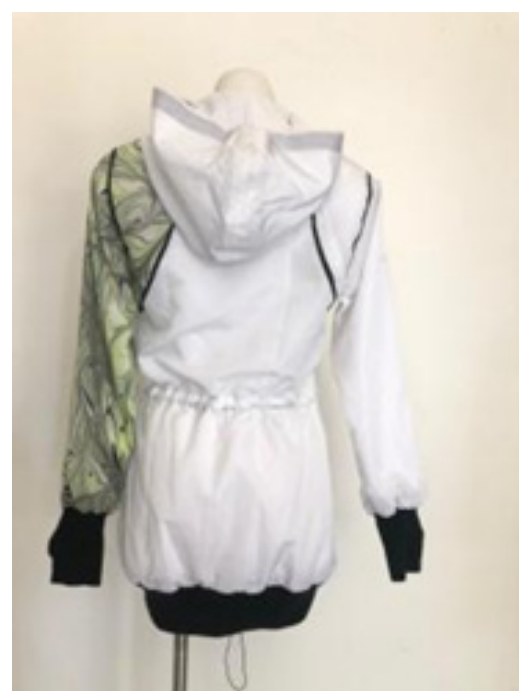

Gambar 14. Cek Volume Prototype Look 3 Tampak belakang Sumber: Toreh, 2021

Dalam bagian final prototype ini merupakan hasil jadi dari desain dengan menggunakan kain asli dan finishing yang rapi. Model yang dipilih untuk menggunakan prototype ini merupakan wanita dengan tinggi $165 \mathrm{~cm}$. 


\section{MODA volume 3 Nomor 2 Juli 2021}

\section{LOOKBOOK}

Hasil dari penelitian perancangan yang sudah dilakukan adalah membuat APD sesuai dengan Look 3, 4 dan 5. Berikut adalah lookbook hasil dari penelitian yang dilakukan:
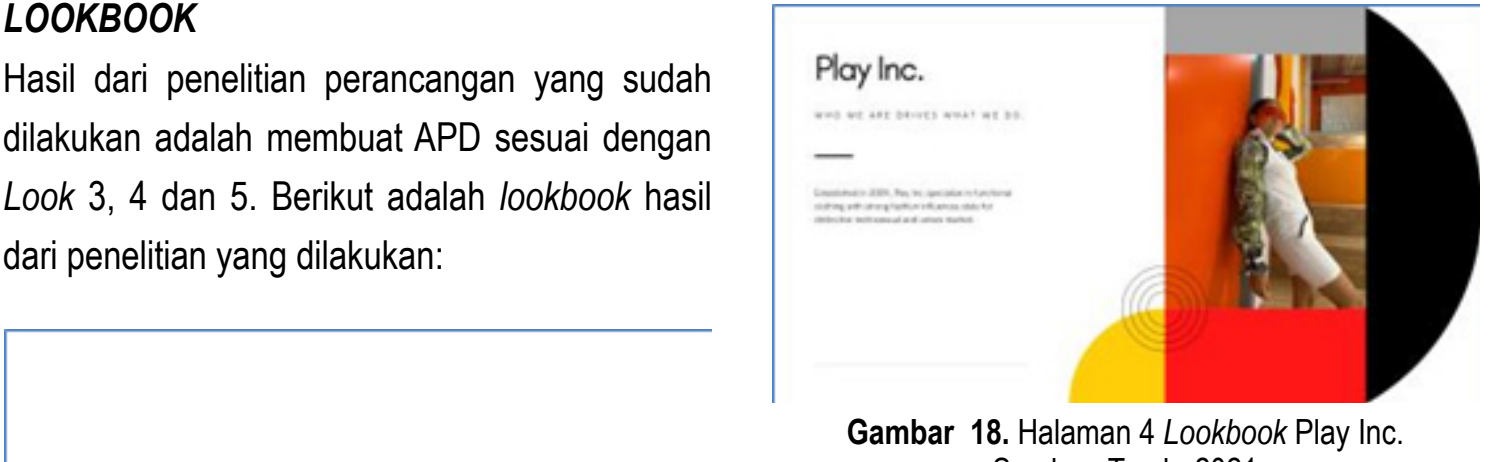

Gambar 18. Halaman 4 Lookbook Play Inc. Sumber: Toreh, 2021

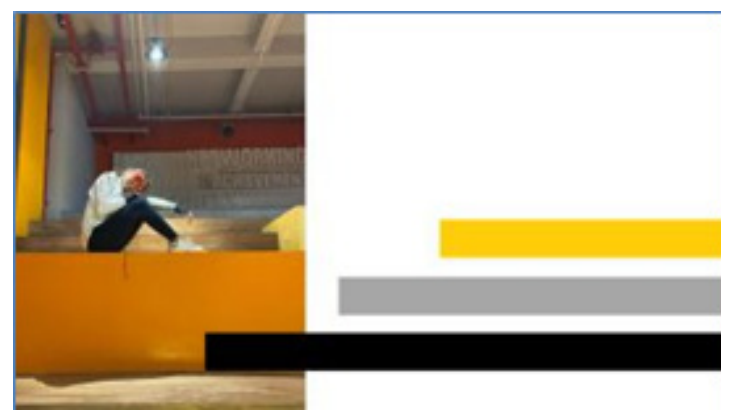

Gambar 19. Halaman 5 Lookbook Play Inc. Sumber: Toreh, 2021 summer issue $21 / 22$
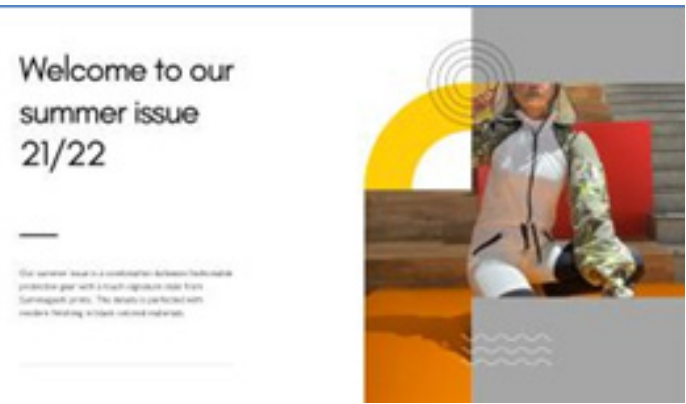

Gambar 16. Halaman 2 Lookbook Play Inc. Sumber: Toreh, 2021

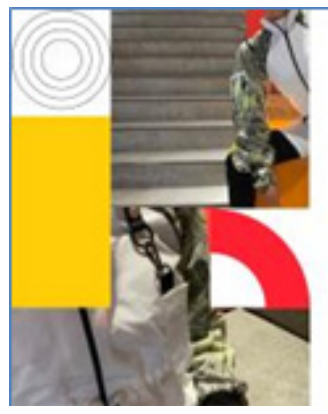

Gambar 17. Halaman 3 Lookbook Play Inc. Sumber: Toreh, 2021

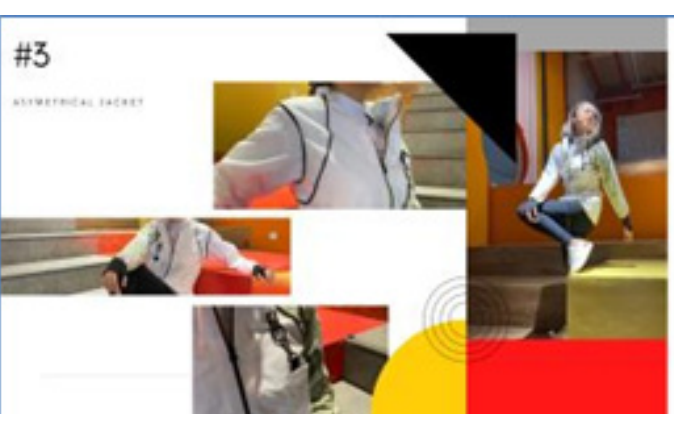

Gambar 20. Halaman 6 Lookbook Play Inc. Sumber: Toreh, 2021

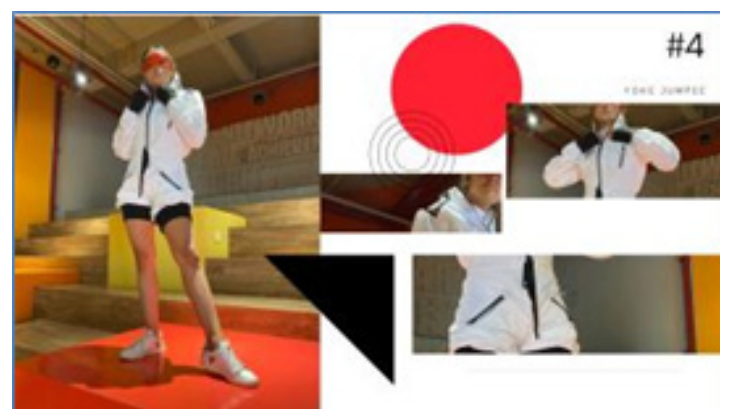

Gambar 21. Halaman 7 Lookbook Play Inc. Sumber: Toreh, 2021 


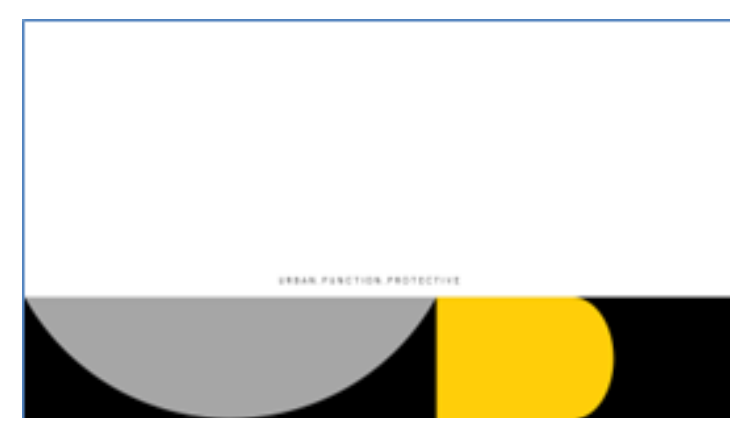

Gambar 22. Halaman 8 Lookbook Play Inc. Sumber: Toreh, 2021

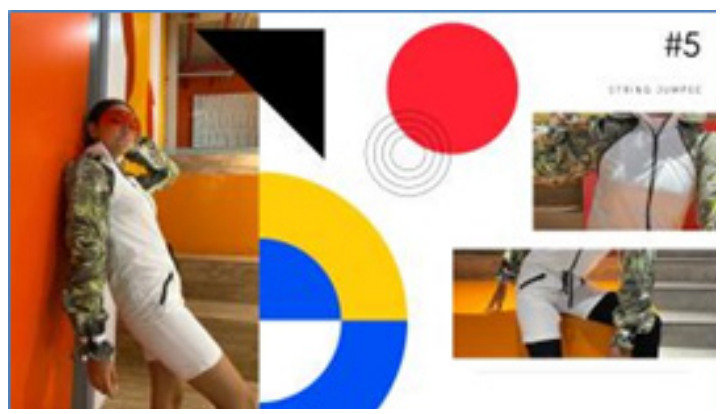

Gambar 23. Halaman 9 Lookbook Play Inc. Sumber: Toreh, 2021

Gambar 24. Halaman 10 Lookbook Play Inc. Sumber: Toreh, 2021

\section{BRAND COLLATERAL}

Setelah lookbook, Brand Play Inc. Juga didukung dengan berbagai aspek lain yang sesuai dengan konsep fashionable APD unisex dengan teknik suminagashi yang dilakukan pada tugas akhir ini. Pemilihan warna Brand Play Inc. yang menggunakan mayoritas warna monochrome dengan tujuan untuk menampilkan ciri khas dari Brand Play Inc. Pada Brand ini ingin mengutamakan serta menampilkan pula esensi dan sisi minimalis dari karakter desain Brand Play Inc.

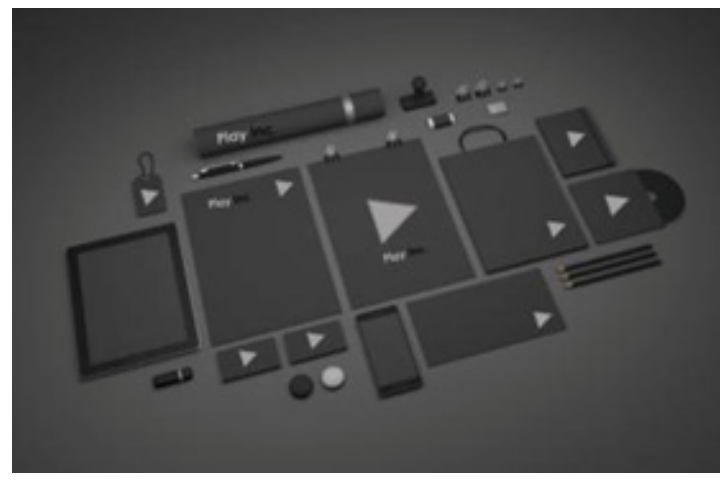

Gambar 25. Brand Collateral Play Inc. Sumber: Toreh, 2021

\section{BRAND PACKAGING}

Selain Brand collateral, Play Inc. juga melengkapi keperluan packaging nya. Brand Play Inc. memiliki banyak varian ukuran yang nantinya ditujukan sesuai dengan besaran jumlah pembelian dari konsumen kami.

Packaging yang disediakan mayoritas menggunakan warna yang masih sesuai dengan desain yang lainnya yaitu monochrome dengan sematan logo Play Inc. yang berupa geometri berbentuk segitiga yang menjadi signature dari Brand. Pada Figur 26 dapat dilihat keseluruhan bentuk serta ukuran packaging yang digunakan dalam Brand Play Inc. 


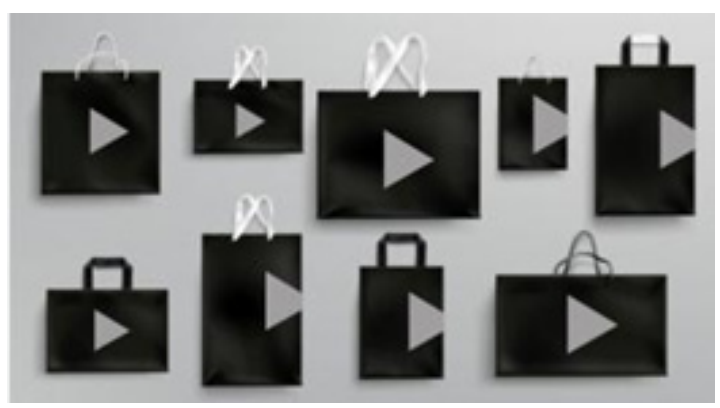

Gambar 26. Brand Packaging Play Inc. Sumber: Toreh, 2021

\section{KESIMPULAN}

Penyebaran virus Covid-19 saat ini masih menjadi sebuah ancaman bagi seluruh masyarakat dunia. Dibutuhkan produkAlat Pelindung Diri (APD) yang dapat digunakan sehari-hari. Namun, produkAPD yang beredar di masyarakat masih mempunyai desain yang mentah dan tidak memperhatikan faktor estetika. Dari permasalahan yang ada tersebut, perancang berusaha mengembangkan sebuah koleksi busana APD dengan desain yang lebih modern, dan dapat diterima masyarakat dengan mengutamakan fitur fungsional untuk mencegah penularan covid19 juga dengan menggunakan bahan yang sesuai dengan keamanan kesehatan yaitu water repellent dan anti microbial. Dari segi estetika, perancang juga mengembangkan implementasi dari teknik Suminagashi pada media kain agar membuat desain lebih menarik dan dipadukan dengan penggunaan warna yang akan menjadi trend pada tahun 2021/22 yaitu hitam, putih dan kuning.

Hasil dari perancangan ini yaitu 3 busana APD berupajaketdanjumpsuitdenganmenganutfungsi adjustable atau dapat menyesuaikan kebutuhan dan ukuran dari pemakai. Hal ini ditunjukkan dengan penggunaan elastic band pada pinggang dan cuff untuk menyeratkan yang dapat diatur sesuai ukuran pinggang dan pergelangan tangan pemakai. Lalu fungsi extension/Plug Ins atau dapat dilepas dan pasang, serta diganti sesuai dengan keperluannya diimplementasikan dengan hoodies dapat dilepas apabila tidak diperlukan sehingga pemakai dapat merasa lebih sejuk. Yang terakhir adalah Modular system atau dapat dipasangkan dengan alat lain yang dapat dilihat pada hoodies dapat dipasangkan dengan face shield.

\section{DAFTAR PUSTAKA}

\section{Buku}

Silalahi, U. (2015). Metode Penilitian Sosial Kuatitatif. Bandung: PT Refika Aditama.

Sugiyono. (2011). Metode Penelitian Kuantitatif. Jakarta: Gramedia.

Wahyutomo, R. (2020). ALAT PELINDUNG DIRI

Tinjauan Konsep Dasar. Kotapraja: Obrasan Kotapraja.

\section{Jurnal}

Eladwi, M. M., \& Kotb, R. M. (2015). Minimalism As A Concept For Textile Finishing and Fashion. International Journal of Textile and Fashion Technology, 1-14.

Hendrawan, A. (2017). Pergeseran Teknik dan Material Marbling pada Tekstil sebagai Konsekuensi dari Perkembangan dan Inovasi. Jurnal Panggung, 1-14. 
Karyono, Rohadin, \& Indriyani, D. (2020).

Penanganan dan Pencegahan

Pandemi Wabah Virus Corona

(COVID-19) Kabupaten Indramayu. Jurnal Kolaborasi Resolusi Konflik, 164-173.

Mubarok, M. H. (2018). Upaya Pedagang Kaki Lima (Pkl) Dalam Pemenuhan Kebutuhan Hidup (Di Jalan Sepakat 2 Kelurahan Bansir Darat Kecamatan Pontianak Tenggara Kota Pontianak). SOCIODEV - Jurnal IImu Sosiatri (Pembangunan Sosial), 101-110.

Patappa, M. M. (2019). Studi Tentang Pembuatan Desain Motif Batik Lontara.Com. Jurnal Imajinasi, 36-47.

Trisnawati, T. Y. (2011). Fashion sebagai Bentuk Ekspresi Diri dalam Komunikasi. Jurnal The Messenger Cultural Studies, IMC and Media, 36-47.

Widyokusumo, L. (2013). Fungsi Garis Pada Desain dan Sketsa. Humaniora, 339347.

Zarkasi, M. S., \& Sukirno. (2018). Abstraksi Figur Punokawan Dengan Teknik Stenling. Brikolase, 31-45.

\section{Internet}

Cesara, L. (2019, Agustus 12). Popbela.com. From style-trend: https://www.popbela. com/fashion/style-trends/lindyracesara/bergaya-minimalis-a-la-streetstyle-star-copenhagen/ 